\title{
PHYLOSOPHIC-ARTISTIC ANALYSIS OF THE ARCHITECTURAL MONUMENT - THE MANSION OF P.I. GADALOV IN THE CITY OF KRASNOYARKS AS A METHOD OF STUDYING VISUAL ARTS
}

\author{
Professor, Doctor of Arts Marina Moskalyuk ${ }^{1}$ \\ Assoc. Prof. PhD (Philosophy) Anastasiya Kistova ${ }^{2}$ \\ Assoc. Prof. PhD (Philosophy) Vladimir Lusan ${ }^{3}$ \\ Master's student Anastasiya Grischenko ${ }^{4}$ \\ Master's student Antonina Fil'ko ${ }^{5}$ \\ ${ }^{1}$ Siberian Federal University, Krasnoyarsk State Institute of Arts, Russia \\ ${ }^{2}$ Siberian Federal University, Krasnoyarsk Arts Museum, named after V.I. Surikov, Russia \\ ${ }^{3}$ Siberian Federal University, Krasnoyarsk Arts Museum, named after V.I. Surikov, Russia \\ ${ }^{4}$ Siberian Federal University, Krasnoyarsk Arts Museum, named after V.I. Surikov, Russia \\ ${ }^{5}$ Siberian Federal University, Krasnoyarsk Arts Museum, named after V.I. Surikov, Russia
}

\begin{abstract}
The modern big city is a space of visual signs. The key role is played by architecture, which, on the one hand, functions as reference points and guiding volumes, on the other hand, is able to influence the outlook and the state of the people passing by. In this connection, the question of how to identify the potential of architectural monuments as visual texts is important.

The work is based on the method of philosophical and artistic analysis of works of architecture as a space of interaction of the viewer and the multifaceted World, presented by the features of external and internal construction of building and specifics of communication of a person with the building.

The article presents the results of the philosophical and artistic analysis of the work of architecture - the mansion of P.I. Gadalov (currently the building of Krasnoyarsk Arts Museum, named after V.I. Surikov) in the city of Krasnoyarsk. With the help of the detailed artistic analysis and philosophical interpretation, the substantial potential of the monument is revealed as a visual text, perceived by a contemporary person.

The conclusion is made about the possibility of communicating with the monument of architecture in its historical context as the former mansion of P.I. Gadalov, as well as in its current function as the building of Krasnoyarsk Arts Museum, named after V.I. Surikov.
\end{abstract}

Keywords: philosophic-artistic analysis, visual potential of architecture, the mansion of P.I. Gadalov, architecture of Krasnoyarsk

\section{INTRODUCTION}

Krasnoyarsk, which was initially established mainly as a commercial and industrial city, owing to the development of gold-mining and shipping in the XIX - early XX centuries, has a number of architectural monuments, representing the "Modern" style in its special Siberian interpretation. Presently one of the best preserved buildings is the mansion of the gild-miner of the first Gild, the merchant Petr Ivanovich Gadalov- which is currently the building of Krasnoyarsk State Arts Museum, named after V.I. Surikov (situated in Parizhskoy Communy Street, 20). The mansion is the only mansion of the beginning of the XX century in the city, which has preserved both exterior appearance and the interior, although with some losses.

In connection with the idea of creating "The Museum Quarter" in the historical centre of the city of Krasnoyarsk by combining the two adjacent buildings in Parizhskoy Kommuny Street, the most important of which is the mansion of P.I. Gadalov, it seems necessary to study the art-symbolic potential of this building- the monument of architecture as a visual text. 


\section{MATERIALS AND METHODS}

The material for the analysis is the building of the former mansion of P.I. Gadalov, which is currently the main building of Krasnoyarsk State Arts Museum, named after V.I. Surikov, in the city of Krasnoyarsk, Russia.

Analysis of the building of the arts museum as visually and sacrally distinguished space is described in the studies of Self R.[1].

The possibility of studying architectural structures as various kinds of visual texts is presented in the works of Parsaeea M., Parvaa M., Karimib B. [2], Xuan G., Wenzheng P., Yi W. [3], Raaphorst K., Duchhart I., Knaap W., Roeleveld G., Brink A. [4], P Mallgrave H.F. [5]. The rich visual potential of Krasnoyarsk architecture is revealed in the study by Sertakova E. A. and Koptseva N. P. [6].

The specifics and peculiarities of applying the method of philosophic-artistic analysis to the study of visual capacities of various works of art and cultural practices is analyzed in the works of V. I. Zhukovskiy [7, 8], N. P. Koptseva [9, 10], E. A. Sertakova [6], M. M. Mirkes [11] and others.

\section{RESULTS}

The original building of the mansion was commissioned by the hereditary honorary citizen, the merchant of the first Guild Pyotr Gadalov (1867-1918) to the architect Vladimir Sokolovsky (1874-1959) for his wife Vera Nikolaevna Gadalova (1867-1940?). The construction started in 1909 and lasted for four years. The the design of the building was created by the sculptor Alexander G. Popov (1865-1930) and the artist Wilhelm Georg (H.) Wagner (1880-1942). The mansion was used for ceremonial receptions.

The building is interesting because it combines a variety of details and techniques of various styles (Modern, Renaissance, Baroque) that are intertwined without violating the integrity of neither the external appearance of the building, nor its interiors. The possible sources for inspiration could be nineteenth century mansions in the style of Modern in the capital, as well as Russian mansions of earlier times, Italian villas and palazzos.

The mansion complex includes such elements as the gates with the railings, the doorkeeper's building, the inner courtyard-garden and the mansion. The building of the mansion is located on the corner of two streets (Parizhskoy Kommuny Street and Karl Marks Street).

The fencing surrounds the building from the street side, interrupting at the entrance portal and the protruding bay window. The fencing has a stone base, on which there is low wroughtiron railing, consisting of a recurring motive of the lotus flower alternating with geometric shapes, echoing the railings of the gates. The inner courtyard-garden is fenced off from the street by the building of the mansion, so that it can be seen only through the railings of the gates.

The building of the mansion has a long curved shape, as it is placed on the corner of the intersection of the streets (Fig. 1). The dominating colour of the façade is yellow with white decorative elements. The building has a gable roof and a scaly dome of green. 


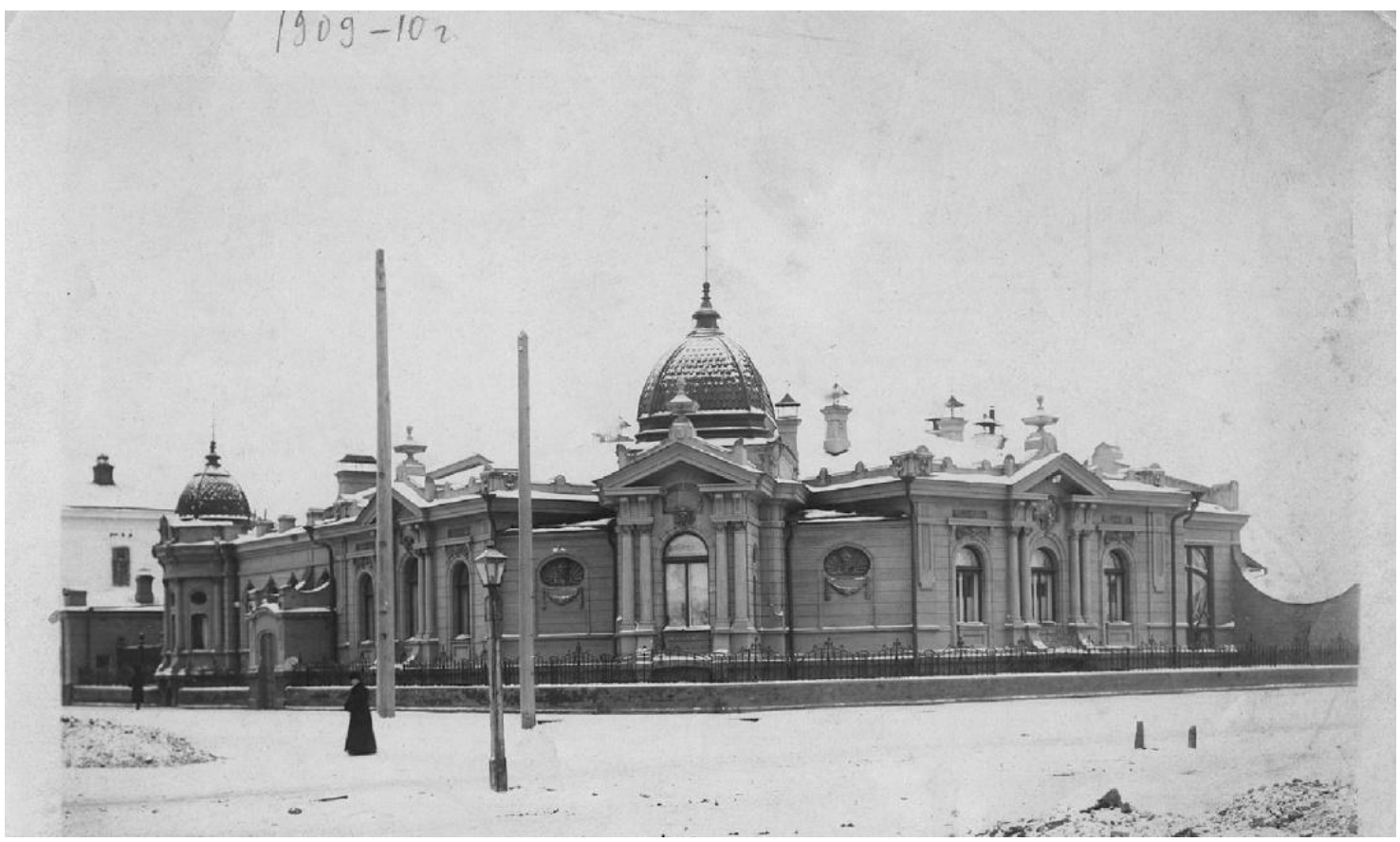

Figure 1. Sokolovskiy V.A. The Mansion of P.I. Gadalov. The view from the intersection of Karl Marx Str. and Parizhskoy Kommuny Str. Russia, Krasnoyarsk. 1909

The street facade of the building is decorated with rustication and has a great number of decorative elements. It can be divided into three parts: the entrance, the main part and the winter garden.

The entrance part of the building begins with a bow window consisting of three windows with small oval embrasures above them. They are decorated with arched niches, separated from each other and from the main plane of the wall with half columns, on the capitals of which there are images of women's faces, leaves and swirls. The frieze features twisted vertical elements and horizontal niches. The cornice is decorated with elements of men's heads. The bay window goes up into the ovoid scaly dome with an oval embrasure. Next to it there are arched windows with twisted elements in the area of the arch keystone and the entrance portal, protruding in relation to the bulk of the building. The roof of the entrance area has a smooth curve. The entrance door, with smooth contours, is located between two columns, going beyond the roof. On the tops of the columns there are griffins with shields and spears in their claws. Between them there is a wrought-iron grille with the initials of V. N. Gadalova. On either side of the door there are two lights. The door itself is decorated with framed carvings. Above the door there is a light window with ornately shaped design, decorated like the other windows in this part.

The main part is symmetrical about the diagonal axis and consists of two avant-corps (risalits), facing the streets and a square bay window on the chamfered corner. The central window of each avant-corps (risalit) is decorated by the pediments, which are supported by paired semi-columns. The space above the window is decorated with an oval mascaron with floral ornaments and a woman's face. Above the pediments there are vases. The other two windows of the avant-corps (risolits) are decorated with mascarons in the form of devils with their mouths open, with leathery wings and twisted horns, with flowers and leaves. The central bay window of the central part has the same design as the central window of the avant-corps (risalits). The side bay windows are decorated in the same way as the semi-circle bay window. On the sides of the bay window there are niches with mascarons depicting a woman on a background of shells and horns of plenty. The head of the woman is also embellished with a shell. Under the mascaron there is a decorative garland of flowers and leaves. Above the bay rises a tall octagonal scaly dome with a spire.

The winter garden retreats inside from the main plane of the of the street side façade. Here almost the whole facade is a large window with a curved pattern of the frames. 
The internal space of the mansion consists of the main staircase, the octagonal hall, two large rooms with alcoves, the space of the winter garden, the space of the corridor, the small rooms (one adjacent to the entrance lobby, the other to the winter garden), the suite of rooms located on the main diagonal axis. There are also two rooms along the axis of the semicircular bay window and the basement (Fig. 2).
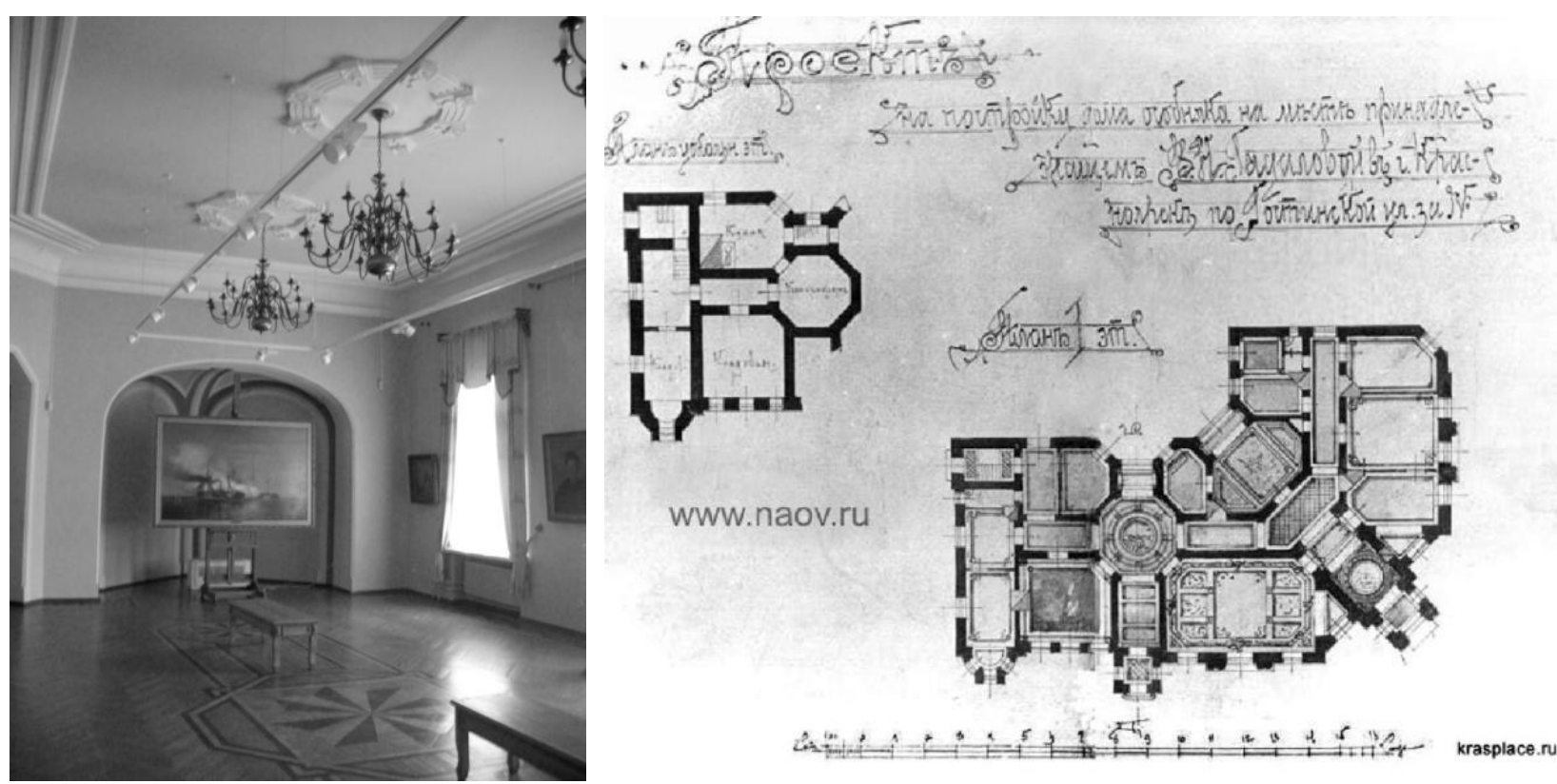

Figure 2. The Mansion of P. I. Gadalov. General view of the great hall to the right of the main staircase and the draft of the plan

The ceilings in almost all the rooms have a multi-banded cornice, echoing the shape of the rooms. The floor is covered with parquet with geometric pattern framing the building along the walls by the alternation of squares and lines. Under the windows the walls are covered with wooden panels with carvings and smooth curves.

Inside the building can be divided into two parts: the exhibition part with the center in the diagonal suite of rooms, and the part for the museum staff. This division is very convenient and logical, it can be seen in the exterior appearance of the building as well, since there are two domes on the roof, located exactly above these centres.

The building of the mansion starts to interact with the audience from outside. The dialogue with the external appearance of the building can be organized in different ways depending on the route.

If you walk along Parizhskoy Komunny Street, the first detail that catches the eye, is the grille on the gate, through which you can see the courtyard-garden, in this way the building makes you interested in what is inside. Further, these gates continue to lead the viewer, but now through the bars of the railings, that repeat the motifs of the gate, until it reaches the semicircular bay window. The columns, decorating the bay window, make a person look up at the dome. And then the viewer comes to the entrance of the mansion, which stands out invitingly from the total bulk of the building.

Watching from Karl Marx Street, the viewer is attracted by the turning shape of the building, with the protruding corner bay windows, richly decorated with the order design with the pediment and the dome on top. Proceeding further, the viewer discovers the protruding entrance doorway.

Upon entering the building a person ascends the stairs and enters the symmetric space of the lobby. The first things you can see entering here are the two mirrors, reflecting the surrounding space and the niche between them (now the museum' ticket office is here). Here a person is faced with the choice of direction of his/her route, because having been given the clear 
direction towards the central niche when entering and going up the stairs, at this point at least three ways open before him/her. He/she can head right away to the room to the left of the stairs (the hall of icons). But he/she can also go straight down the corridor to the hall, devoted to V.I. Surikov (the former winter garden) and on the way back look into the other rooms. Or alternatively he/she can start their route with the suite of rooms with alcoves (to the right of the stairs), and then make a loop in the corridor through the former winter garden. The area of the mansion gives a person a free choice of his/her route, creating different ways of communication between the rooms, and thus, for building the dialogue with not only the space of the building, but also with the works of art, exhibited here. The architecture of the mansion as a museum gives the opportunity to communicate with both small works of art and large-scale ones, with both paintings and music, since there are musical instruments in the alcoves of the rooms. You can communicate while in the company of other people, or retire in a smaller space of the smaller rooms and bays.

Thus, whichever way a person chooses for passing through the rooms of the mansion, in the end he/she will still have to return to the lobby with the mirrors. And at the end of his/her communication with the mansion, the viewer descends the staircase and goes back out into the bustling street.

In this context (given its modern function of the museum) the mansion appears to be the ideal place for a person's communication with works of art, with the world and with him/herself. No wonder it looks like a temple, due to the use of domes in the design, reminding of a religious building. The special status of this space is also emphasized by the presence of the griffinsguards at the entrance that will not let pass inside a person, who is not appropriately tuned and prepared.

It is worth noting that all the elements of the exterior of the building seek to force a person to raise his/her eyes to the top, from whatever side he/she approaches it. It all starts with the railings, which direct our attention upwards with their floral pattern, ending with an upward looking stamen. It is followed by the stucco décor of a column, which force the viewer to look up to the eaves. And then, following the pediment or rounded window, the eye reaches the dome, with the spire pointing to the sky. Thus, the external appearance of the building compels us to break away from the mundane problems and thoughts and seek something more sublime and prepare for communication with works of art.

It is known that during the time when the mansion belonged to the Gadalovs, the interior of the building was decorated by paintings and stained glass windows with fairy tale themes, and in the basement there was a little museum: "In honor of completion of the work, dad and I were invited to dinner, and I got permission to walk around the rooms. Most of all I liked dad's job. From the street entrance, the front door was raised above the level of sidewalk, there was an internal staircase on both sides of which guests-merchants from Pushkin's "The tale of Tsar Saltan" were depicted. The lobby did not have direct light, and was separated from the window by the wonderful stained glass, whose coloured glass made a mosaic picture: there was the Firebird, flowers, and leaves. From the entrance hall the doors led into the inner rooms. Above the door to the dining room there was the inscription in Slavic script: "Eat bread and salt and tell the truth". In the bays... there were sofas. And on the floor lay rugs of bear skins - brown and white. On the sofas there were many pillows, embroidered by Vera Petrovna, the daughter of Gadalov.

Vera Petrovna received her guests in her rooms, where the walls, like in the exhibition, were covered by many framed pictures, embroidered by the hostess. She sent me to count all the pillows in the house, or to explore the winter garden and the museum, located in the basement of the building. At the entrance to the museum stood a warrior with a sword, in chain mail-armour and steel helmet, there were many old utensils and bowls around... In the winter garden there was a huge window the size of the wall, facing Yzen'kaya ("narrow") Street. There was a tall palm reaching to the ceiling and a lot of tropical flowers and free-flying parrots" [12]. 
Upon entering the space of the mansion, the building compels you not only to raise your eyes but to rise physically up the stairs. And get into the ideal space of the lobby. Here there is the same number of arches on the sides. The paired doors are echoed by the paired mirrors that balance the space, making it symmetrical. And the first thing we see in the lobby, is ourselves reflected in the two mirrors. We also see a checkpoint in the form of the ticket-office between them. We find ourselves in some space of choice. You can turn back to the stairs and go out. You can go to the coat-check with the ticket-office, buy a ticket, find out information. You can look through the apertures to see if there is something interesting there, and perhaps to already plan the route around the exhibition. Or to look at yourself, given the double opportunity to see yourself in the two mirrors. No wonder there is a kind of floor compass in the shape of the pattern, indicating the possible variations of the route, which depend on the person, and allowing you to evaluate your desires and capabilities. There is a kind of compass on the floor of almost every room. They are absent only in straight corridors and rooms with a single door.

It is important to remember that there is not one entrance hall in the mansion. There is another entrance through the courtyard, even if it is not available. But it works differently. Firstly, entering from the yard, we cannot experience the impact of the street-facing façade of the building, especially if you walk down Parizhskoy Kommuny Street from Mira Prospect, and this means that we can miss the visual ascent. Secondly, the physical rising will not take place because the door facing the courtyard is at the level of the floor. Thirdly, despite the compass on the floor of this lobby, it is not the space for choice. Because there are only two ways here forward and backward. Even if we go to the corridor, crossing this straight line, we will still find changing the route difficult, because even the lines of the walls of the corridors direct the straight movement towards the space under the dome. Of course, once there, we will be able to continue our way in any direction, but our moving will not be completely free.

While going through all the areas of the mansion we constantly see the elements that guide our view to the top and keep us toned. Geometric patterns seem to go upwards, mingling with vegetation ones. This can be seen in the carvings on the doors and the stucco details of the walls. This is particularly clear in the middle space of intersection of the suite of rooms and corridors, where strict Doric columns with cubic bases suddenly end in lotus caps and blossom with ornate floral pattern. You can explicitly trace the metaphor of movement and change, present in the whole space of the mansion. Parquet patterns in the center of the halls not only set the direction, being a kind of compass, but are also in constant motion, due to the central motifs of the patterns (the eight-pointed star, the mill) similar to the symbol of Kolovrat. Transformation of geometric shapes (situated closer to the floor, and, hence, to the viewer) in the vegetation shapes (situated closer to the ceiling) can be seen as the transformation of non-natural, man-made, into natural. Thereby, the decoration of the floor, doors and walls encourages the viewer to not just rise above the mundane, but also to reconnect with the natural world.

To complete the walk around the mansion, we are forced to return to the point from which we started our choice. And here again, the person is confronted with himself, with his reflection in the space of the mansion. No matter which way he went, one of the mirrors will still be in his sight. So, we, as contemporary visitors to the mansion - museum are not only presented with the possibility of communication with the works of art, but also with the opportunity to assess ourselves before and after this communication.

\section{DISCUSSION AND CONCLUSION}

Philosophic-artistic analysis of the building of the mansion (currently Krasnoyarsk Arts Museum, named after V.I. Surikov) has pointed out that the monument of architecture, interacting with people, is an image of the ideal space for a person's socializing with the world, society and him/herself through art works. The decor of the facade and interior space make us rise above the mundane and everyday and sets the internal transformation. The construction of the passages between rooms creates a comfortable environment for interaction with the artworks and the diversity of forms of space of the mansion-museum allows you to have a variety of 
experiences, both public and intimate, of communication with the works of art. The conducted study shows that the building has a rich visual potential and is able to interact with the person in its historical context as the former mansion of the spouse of the Krasnoyarsk merchant and philanthropist P. I. Gadalov, as well as its modern function as the building of the Krasnoyarsk Arts Museum, named after V.I. Surikov.

The presented viewpoint reveals the potential of architectural constructions not in full, since the method of philosophical-art analysis considers the works of art mainly in their possible perception by a modern person, acting as a viewer. The analyzed building structure has also a rich historical potential that can be revealed by the methods of typological, stylistic and historical analysis.

The selected methodology allows us to focus on those aspects of the visual potential of the monument, which are most relevant and are in demand among the residents and guests of the city during their everyday trips or special visits to the building in its capacity of a museum.

Based on the results of the study, the program of actualizing the revealed meanings in the city and socio-cultural environment of Krasnoyarsk can be formed, in the process of creating the project "The Museum Quarter".

\section{ACKNOWLEDGEMENTS}

The study was supported by the Regional State Autonomous Institution "Krasnoyarsk Regional Fund of Support of Scientific and Scientific-Technical Activities".

\section{REFERENCES}

[1] Self R. The Architecture of Art Museums: A Decade of Design: 2000 - 2010, USA, 2014.

[2] Parsaeea M., Parvaa M., Karimib B. Space and place concepts analysis based on semiology approach in residential architecture: The case study of traditional city of Bushehr, Iran,HBRC Journal, Iran, vol. 11/issue 3, pp 368-383, 2015.

[3] Xuan G., Wenzheng, P. Yi W. Architectural Semiotics and Urban Cultural Heritage Interpretation: A Case Study of Urban Historical Heritage Presentation in Chongqing, Urban Insight, China, 2014. - doi: http://en.cnki.com.cn/Article_en/CJFDTOTALCSGC201405008.html

[4] Raaphorst K., Duchhart I., Knaap W., Roeleveld G., Brink A. The semiotics of landscape design communication: towards a critical visual research approach in landscape architecture, Landscape Research, Netherlands, vol. 42/issue 1, pp. 120-133, 2016.

[5] Mallgrave H.F. Enculturation, Sociality, and the Built Environment, Architecture and Empathy, USA, pp. 20-41, 2015.

[6] Sertakova E. A., Koptseva N. P. Socio-cultural space of modern Russian city (based on the analysis of the city of Krasnoyarsk): monograph, Russia, 2015.

[7] Zhukovskiy V. I. Theory of the fine arts, Russia, 2011.

[8] Zhukovskiy V. I., Koptseva N. P. Art as a vital necessity. Visual art, Art and education, Russia, 3, pp. 5-29, 2010.

[9] Koptseva N. P. Moskalyuk M. V., Pimenova N. N., Mirkes M. M. and others. The New art critic on the banks of the Yenisei river: monograph, Russia, 2015.

[10] Koptseva N.P., Reznikova K.V. Refinement of the Causes of Ethnic Migration North Selkups Based on the Historical Memory of Indigenous Ethnic Groups Turukhansk District of Krasnoyarsk Krai, Bylye Gody, vol. 38/issue 4, pp. 1028-1038, 2015.

[11] Mirkes M. M., Sergeeva N. Codification of the cultural meanings in the ornaments of the streets of the city of Krasnoyarsk, Journal of Siberian Federal University. Humanitarian Sciences, Russia, 4, 12, pp. 1794-1806, 2011.

[12] Pichugin O.K. Wilhelm Wagner is an artist and teacher, Surikov readings: scientificpractical conference, Russia, pp. 38 - 41, 2006. 